Beerstecher, E. \& Edmonds, E. J. (1951). J. biol. Chem. 192, 497.

Conway, E. J. \& O'Malley, E. (1942). Biochem. J. 36, 655.

Dawes, E. A. \& Happold, F. C. (1949). Biochem. J. 44, 349.

Fildes, P. \& Rydon, H. N. (1947). Brit. J.exp. Path. 28, 211.

Friedemann, T. E. \& Haugen, G. E. (1943). J. biol. Chem. $147,415$.

Gale, E. F. (1951). Bacterial Physiology, p. 445. New York: Academic Press, Inc.
Groves, L. H. \& Swann, G. A. (1951). J. chem. Soc. p. 1142.

Happold, F. C. \& Hoyle, L. (1934). Biochem. J. 28, 1171.

Tatum, E. L. \& Bonner, D. (1944). Proc. nat. Acad. Sci., Wash., 30, 30.

Umbreit, W. W. \& Wadell, J. G. (1949). Proc. Soc. exp. Biol., N.Y., 70, 293.

Wendl, W. B. (1931). J. biol. Chem. 94, 717.

Wood, W. A., Gunsalus, I. C. \& Umbreit, W. W. (1947). J. biol. Ohem. 170, 313.

Woods, D. D. (1935). Biochem. J. 29, 640.

\title{
A Note on the Action of Fluoroacetate
}

\author{
By J. D. JUDAH AND K. R. REES \\ Department of Morbid Anatomy, University College Hospital Medical School, \\ and Department of Biochemistry, University College, London
}

(Received 24 March 1953)

Liébecq \& Peters (1949) showed that the inhibitory action of fluoroacetate on the oxidation of pyruvate and fumarate could not be accounted for by the postulated comp titive inhibition of acetic acid oxidation (Bar lett \& Barron, 1947). They demonstrated that citrate accumulated during the oxidation of fumarate and pyruvate and suggested that fluoroacetate after activation underwent a condensation to form a fluorotricarboxylic acid. This hypothesis has since been confirmed (Buffa, Peters \& Wakelin, 1951) and the inhibitor, presumably fluorocitric acid, has been isolated in crystalline form (Peters, Wakelin \& Buffa, 1951). These authors state that this is apparently not a simple case of competitive inhibition, because of the straight-line relation which was found between the active substance and the effect upon citrate disappearance. They used however only one concentration of citrate. Although the theory of competitive inhibition can only be applied with reserve to a multienzyme system contained in particles such as mitochondria, it seemed of interest to apply the method of Lineweaver \& Burk (1934) to the system; we have therefore examined the effect of fluorocitrate on citrate oxidation by rabbit-kidney mitochondria at various concentrations of substrate and inhibitor. These experiments were done in 1950 during another investigation (Judah \& Rees, 1953) and are published here in the hope that the results might be of interest to others.

\section{Methods}

Mitochondria from rabbit kidney were obtained by the method of Schneider (1948) using $0.25 \mathrm{M}$ sucrose as the medium.

Oxygen uptake was measured manometrically in a Warburg apparatus in air at $38^{\circ}$. Initial velocities were taken as $\mu \mathrm{l} . \mathrm{O}_{2}$ uptake in the first $5 \mathrm{~min}$. after $10 \mathrm{~min}$. equilibration.

Citrate was estimated by the method of Weil-Malherbe \& Bone (1949).

\section{Materials}

Adenosine 5' -phosphate obtained commercially was crystallized twice from hot water. By spectrophotometric analysis (Kalckar, 1947) and paper chromatography (Hanes $\&$ Isherwood, 1949) it was pure.

Sodium citrate was a commercial preparation.

Sodium fluoroacetate was provided by Dr R. A. E. Galley of the Agricultural Research Council.

Cytochrome $c$ was prepared by the method of Keilin \& Hartree (1937) and dialysed against distilled water.

Composition of the medium: inorganic phosphate $0.025 \mathrm{M}$, pH 7.4; adenosine 5'-phosphate 0.001 м; $\mathrm{MgSO}_{4}$ 0.0067 M; $\mathrm{KCl} 0.025 \mathrm{M}$; cytochrome $c 1 \times 10^{-5} \mathrm{M}$; mitochondrial suspension in $0.25 \mathrm{M}$ sucrose; and water to a final vol. of $3 \mathrm{ml}$.

\section{RESULTS}

During investigations on the action of fluoroacetate on citrate oxidation by rabbit-kidney mitochondria we observed that the inhibition was slight in the early part of the experiment and then progressed. Table 1 shows a typical experiment representative

\section{Table 1. Progressive inhibition of citrate oxidation by fuoroacetate}

System: standard medium as described in text. $10^{-3} \mathrm{M}$ fluoroacetate; citrate, $30 \mu$ moles. Enzyme, rabbit-kidney mitochondria. All present initially.

\begin{tabular}{lcc} 
& \multicolumn{2}{c}{$\mathrm{O}_{2}$ uptake $(\mu \mathrm{l})}$. \\
\cline { 2 - 3 } & $\overbrace{\text { Fluoroacetate }}$ & No fluoroacetate \\
lst $10 \mathrm{~min}$. & 236 & 236 \\
2nd 10 min. & 95 & 203 \\
3rd 10 min. & 90 & 210
\end{tabular}


of five. This result suggested a competitive inhibition, and we decided to apply the methods of Lineweaver \& Burk (1934) to our system. A preliminary experiment was carried out to obtain a value for the Michaelis constant $K_{m}$.

Fig. 1 shows an experiment in which two concentrations of fluoroacetate and five concentrations of citrate were used. In this experiment citrate was placed in the side arm of the flask while fluoroacetate and $3 \mu$ moles of L-malate were placed in the main compartment to ensure activation of the inhibitor before citrate came into contact with the enzyme system. This arrangement permitted the formation of the active inhibitor, fluorocitrate, so that when citrate was added to the centre compartment of the flask an immediate inhibition of its oxidation was always observed. Fig. 1 shows that the criteria for competitive inhibition are met. These curves were analysed by the method of least squares. This experiment was repeated four times with the same result.

Calculation gives values for $K_{i}$ between $1 \cdot 1 \times 10^{-4}$ and $2.1 \times 10^{-4} \mathrm{M}$. $K_{m}$ was $4.5 \times 10^{-4} \mathrm{M}$. The variations in $K_{i}$ can probably be explained by the incomplete activation of fluoroacetate and are certainly too high as they relate to the fluoroacetate concentrations rather than to the unknown concentration of the active inhibitor. Sir Rudolph Peters has drawn our attention to the possibility that synthesis of fluorocitrate continues throughout the experiment and that this would make the analysis extremely complex. However, a compari-

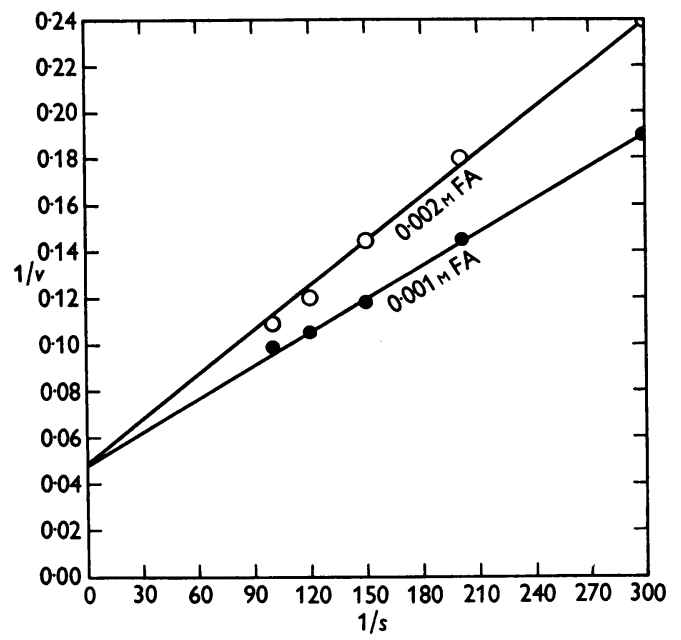

Fig. 1. Demonstration of competitive inhibition between citrate concentrations $(S)$ of 0.01 and 0.0033 M. System: standard medium. Fluoroacetate (FA) was present in the main compartment of the flask, together with $3 \mu$ moles L-malate. Citrate was tipped from the side arm at the end of equilibration (10 min.). $v=\mathrm{O}_{2}$ uptake in first $5 \mathrm{~min}$. son of a control system such as described in Table 1 with one to which 2:4-dinitrophenol (DNP) was added $10 \mathrm{~min}$. after the beginning of the experiment showed no difference in the degree of inhibition. This suggests that there is no continuous synthesis of fluorocitrate as DNP has been shown (Judah \& Rees, 1953) to block the formation of fluorocitrate. Table 2 shows the disappearance of citrate at five concentrations in the presence of $0.002 \mathrm{M}$ fluoroacetate. It will be observed that citrate disappearance varies with the initial citrate concentration. This experiment was done to confirm by chemical means the manometric experiment illustrated in Table 1.

These experiments were carried out at citrate concentrations between 0.01 and $0.0033 \mathrm{M}$. Buffa et al. (1951) were unable to demonstrate a competitive inhibition, but they used a single concentration of citrate. This was $10 \mu \mathrm{moles} / 3 \mathrm{ml}$., i.e.

Table 2. The effect of citrate concentration on citrate disappearance in the presence of fluoroacetate

System: standard medium as described in text. Fluoroacetate (final concn. $0.002 \mathrm{M}$ ) and $3 \mu$ moles of L-malate were placed in the main compartment of the flask. Citrate was tipped from the side arm at the end of equilibration (10 min.). Duration of experiment 20 min.

$\begin{array}{cc}\begin{array}{c}\text { Citrate } \\ \text { concentration } \\ (\mathrm{M})\end{array} & \begin{array}{c}\text { Citrate } \\ \text { disappearance } \\ (\mu \text { moles })\end{array} \\ 0.01 & 10 \\ 0.0083 & 7 \\ 0.0067 & 3 \\ 0.005 & 2 \\ 0.0033 & 1\end{array}$

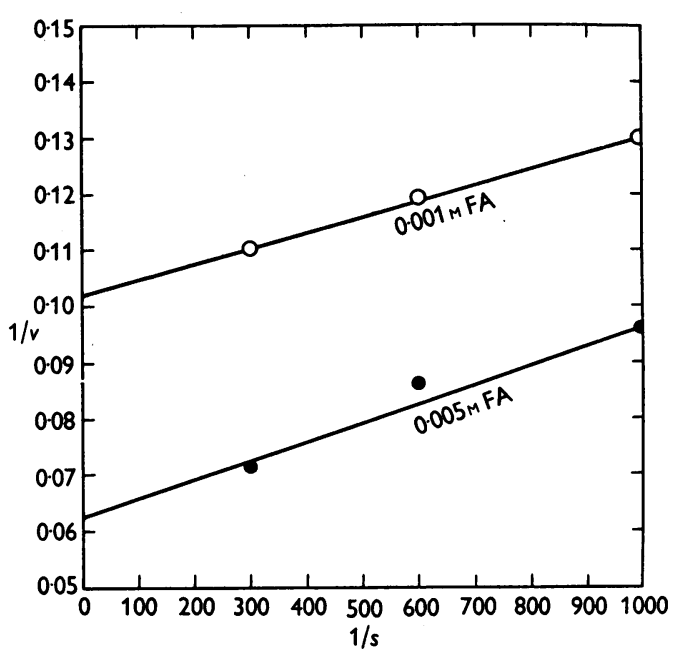

Fig. 2. Demonstration of non-competitive inhibition below citrate concentration of $0.0033 \mathrm{M}$. Conditions as in Fig. 1. $v=\mathrm{O}_{2}$ uptake in first $5 \mathrm{~min}$. after $10 \mathrm{~min}$. equilibration. 
$0.0033 \mathrm{M}$. An experiment carried out with citrate concentrations between 0.001 and $0.0033 \mathrm{M}$ showed non-competitive inhibition. Fig. 2 illustrates this experiment. Though it would appear possible to combine Figs. 1 and 2, this is not permissible as they were obtained from different experiments.

\section{DISCUSSION}

Elliot \& Kalnitsky (1950) showed a competitive inhibition by fluoroacetate of citrate oxidation by rabbit-kidney preparations. They claim that the oxidation of cis-aconitate was not inhibited by fluoroacetate and in fact was accelerated. This result is difficult to explain in view of the findings of Peters \& Wilson (1952), who used a soluble aconitase together with a purified sample of the active inhibitor (fluorocitrate) and showed a competitive inhibition of this enzyme by the method of Lineweaver \& Burk (1934). They observed that a noncompetitive type of inhibition might occur if time were not allowed for the enzyme, substrate and inhibitor to come to equilibrium before measuring the initial velocity of the reaction. We have observed competitive inhibition between citrate concentration of 0.01 and $0.0033 \mathrm{M}$, whereas below the latter concentration inhibition was non-competitive. We are at present unable to explain this result.

\section{SUMMARY}

1. The effect of fluoroacetate on citrate oxidation by mitochondrial systems has been investigated.
2. The apparent competitive nature of this inhibition has been demonstrated with citrate concentrations of $0.01-0.0033 \mathrm{M}$.

3. Below $0.0033 \mathrm{M}$ citrate concentration the inhibition is non-competitive.

The authors wish to express their gratitude to Prof. E. Baldwin and Prof. G. R. Cameron, F.R.S., for their interest in this work and their constant encouragement.

This work was supported by grants to us by the Medical Research Council, the Agricultural Research Council and the Graham Research Fund, University of London. These are gratefully acknowledged.

\section{REFERENCES}

Bartlett, G. R. \& Barron, E. S. G. (1947). J.biol. Chem.170, 67.

Buffa, P., Peters, R.A. \& Wakelin, R. W. (1951). Biochem.J. 48, 46.

Elliot, W. B. \& Kalnitsky, G. (1950). J. biol. Chem.186, 487.

Hanes, C. S. \& Isherwood, F. A. (1949). Nature, Lond., 264, 1107.

Judah, J. D. \& Rees, K. R. (1953). Biochem. J. 55, 664.

Kalckar, H. M. (1947). J. biol. Chem. 167, 461.

Keilin, D. \& Hartree, E. F. (1937). Proc. Roy. Soc. B, 122, 298.

Liébecq, C. \& Peters, R. A. (1949). Biochim. biophys. Acta, 3, 215 .

Lineweaver, H. \& Burk, D. (1934). J. Amer. chem. Soc. 56, 658.

Peters, R.A., Wakelin, R. W. \& Buffa, P.(1951). Biochem. J. 50, 13.

Peters, R. A. \& Wilson, T. H. (1952). Biochim. biophys. Acta, 9, 310.

Schneider, W. C. (1948). J. biol. Chem. 176, 259.

Weil-Malherbe, H. \& Bone, A. D. (1949). Biochem.J.45, 378.

\title{
Studies in Carotenogenesis
}

\section{CAROTENOID SYNTHESIS IN THE ALGA HAEMATOCOCCUS PLUVIALIS}

\author{
By T. W. GOODWIN AND MALINI JAMIKORN \\ Department of Biochemistry, The University of Liverpool
}

(Received 19 November 1953)

\begin{abstract}
Haematococcus pluvialis is a unicellular, motile, green alga of the class Chlorophyceae. Like that of most flagellates its resting stage is characterized by the production of cysts, the formation of which is generally regarded as a response to unfavourable environmental conditions, although this may not always be so (see Fritsch (1935) for a full discussion). Formation of cysts in algae is very often accom. panied by a change in colour from green to orange or red, and it was in the naturally occurring (red) encysted form of $H$. pluvialis that astaxanthin (3:3'-diketo-4:4'-dihydroxy- $\beta$-carotene) was first
\end{abstract}

found in plant tissues (Tischer, 1937, 1944); it was accompanied by small amounts of $\alpha$ - and $\beta$-carotenes and lutein. Until that time astaxanthin had been found only in animal tissues, but since then it has also been found in the, presumably encysted, algae, Brachiomonas simplex and Protosiphon botryoides (Bielig, 1947). (It should be noted, however, that Strain (1951) believes that there are two ketonic carotenoids in $P$. botryoides, neither of which is astaxanthin.)

Another well-known example of a red-encysted alga is Trentepholia aurea, the resting stage of 